\title{
The Profile of Law Clerks Using Judiciary Informatics in Turkey ${ }^{*}$
}

\author{
Zerrin Sungur ${ }^{1}$, Özlem Alpu ${ }^{2}$, Özlem Oktal ${ }^{3}$, and Berna Yazıcı ${ }^{4}$ \\ ${ }^{1}$ Anadolu University Faculty of Economics and Administrative Sciences, \\ Department of Labor Economics and Industrial Relations 26470 Eskisehir-Turkey \\ ${ }^{2}$ Eskisehir Osmangazi University Faculty of Arts and Sciences, \\ Department of Statistics 26480 Eskisehir-Turkey \\ ${ }^{3}$ Anadolu University Faculty of Economics and Administrative Sciences, \\ Department of Business Administration 26470 Eskisehir-Turkey \\ ${ }^{4}$ Anadolu University Faculty of Science, Department of Statistics 26470 Eskisehir-Turkey \\ \{zsungur, odogan, bbaloglu\} @anadolu . edu.tr, \\ oalpu@ogu.edu.tr
}

\begin{abstract}
The automation of judicial services got it's start in 1998 in Turkey. In order to increase performance and productivity of these services many regulations have been made in parallel with the innovations and improvements realized in the sector of information technologies. There are many internal users using the judiciary informatics such as chief judges, judges, attorneys general, solicitors, prison officers and law clerks. The aim of this study is to analyze the profile of the law clerks using judiciary informatics in Turkey and evaluate their uses of judiciary informatics in terms of the dimensions of performance and effort expectancy, attitude toward using technology, security and risk and anxiety. Web based questionnaire, which was prepared as a five-point Likert type scale including 4898 law clerks, was analyzed through factor analysis. The empirical research was carried out between July and August 2012 in Turkey.
\end{abstract}

Keywords: law clerks, e-government, judiciary informatics, Turkey.

\section{Introduction}

Judicial services have been undergoing a rapid transformation in late 1990s due to the impact of the technological changes. They enabled the delivery of services over the Internet. The automation of judicial services got it's start in 1998 in Turkey. In order to increase performance and productivity of these services many regulations have been made in parallel with the innovations and improvements realized in the sector of information technologies. Information systems that are scalable, multi-user and workbased systems came into question in order to increase performance and productivity of institutions. The automation of judicial services is an important step among the

\footnotetext{
This study was supported by Anadolu University Scientific Research Projects Commission under the grant no: 1203E045.
} 
e-government practices. Some of the contributions of judiciary informatics can be sited as speed, accuracy, consistency, transparency, effectiveness and efficiency and saving ${ }^{1}$.

\section{The Job of Law Clerks}

Some studies indicate that the early practice was very largely against the emergence of the law clerks as a constantly changing group of inexperienced but bright and welltrained young law-school graduates ${ }^{2}$. The first official reference to the idea of employing assistants for the Supreme Court justices occurred in $1885^{3}$. The job of law clerk has evolved in name as well as in substance as up from 'secretary', for the 'law clerks', 'law assistant', 'research aide', 'legal assistant' and also 'law examiners'

Knowledge, experience and education are required for a law clerk. He/she has to be knowledgeable about laws, court procedures and government regulations. Also he/she to be knowledgeable about administrative and clerical procedures and systems such as word processing, managing files and records, stenography and transcription, designing forms, and other office procedures and terminology. Knowledge of circuit boards, processors, chips, electronic equipment, and computer hardware and software, including applications and programming are also crucial skills for law clerks.

Job duties of law clerks vary between countries, but some common tasks are;

- preparing affidavits of documents and maintain document files and case correspondence,

- searching for and studying legal documents to investigate facts and law of cases, to determine causes of action and prepare cases,

- researching and analyzing law sources to prepare drafts of beliefs or arguments for review, approval, and use by attorney,

- reviewing and filing pleadings, petitions and other documents relevant to court actions,

- serving copies of pleas to opposing counsel,

- communicating and arbitrating disputes between parties.

\section{The Aim of the Study}

The aim of this study is to analyze the profile of the law clerks using judiciary informatics in Turkey and evaluate their uses of judiciary informatics in terms of the dimensions of performance and effort expectancy, attitude toward using technology, anxiety, and security and risk.

http://www. uyap.gov.tr/tanitim/tarihce.html

2 Newland, C. A.: Personal Assistants to Supreme Court Justices: The Law Clerks. Oregon Law Review. 40316 (1961).

3 Mahoney, J. D.: Law Clerks: For better or for Worse? Brooklyn Law Review. 54323 (1988).

4 Baier, P. R.: The Law Clerks: Profile of an Institution. Vanderbilt Law Review. 261130 (1973). 


\section{$4 \quad$ Sampling and Obtaining Data}

Prepared web based questionnaire was applied to all of internal users including law clerks by The Ministry of Justice General Directorate of Information Technologies and 8840 internal users replied. The population size is 76 592. The internal users, chief judges, judges, attorneys general, solicitors, prison officers and law clerks, were assigned to the questionnaire. The empirical research was carried out between July and August 2012 in Turkey. The sample size of law clerks was 4898. Data were analyzed by SPSS 21.0.

\section{$5 \quad$ Findings and Evaluation}

The profile of law clerks based on their demographic characteristics was shown in Table 1. The demographic findings indicate that $61.55 \%$ of law clerks are male and $38.45 \%$ are female respectively. Of the respondents, $16.90 \%$ are between $18-24$ years of age, $62.62 \%$ are between $25-34,16.39 \%$ between $35-44,4.09 \%$ are 45 years and over.

Table 1. Law clerks' demographic characteristics

\begin{tabular}{|c|c|c|c|}
\hline Variable & Variable level & $\begin{array}{l}\text { Frequency } \\
(n=4898)\end{array}$ & $\%$ \\
\hline \multirow[t]{2}{*}{ Gender } & Female & 1883 & 38.45 \\
\hline & Male & 3015 & 61.55 \\
\hline \multirow[t]{4}{*}{ Age } & $18-24$ & 828 & 16.90 \\
\hline & $25-34$ & 3067 & 62.62 \\
\hline & $35-44$ & 803 & 16.39 \\
\hline & 45 years and over & 200 & 4.09 \\
\hline \multirow[t]{5}{*}{ Educational status } & Secondary school & 8 & 0.16 \\
\hline & High school & 1285 & 26.23 \\
\hline & MA degree & 3466 & 70.76 \\
\hline & MBA degree & 137 & 2.79 \\
\hline & Doctorate & 2 & 0.04 \\
\hline \multirow[t]{5}{*}{ Work Experience } & Less than 1 year & 768 & 15.67 \\
\hline & $1-5$ years & 2103 & 42.93 \\
\hline & $6-10$ years & 1359 & 27.74 \\
\hline & $11-15$ years & 323 & 6.59 \\
\hline & 16 years and over & 345 & 7.04 \\
\hline \multirow{3}{*}{$\begin{array}{l}\text { Experience of the use } \\
\text { of information system }\end{array}$} & $1-3$ years & 2488 & 50.80 \\
\hline & $4-6$ years & 1969 & 40.20 \\
\hline & 7 years and over & 441 & 9.00 \\
\hline
\end{tabular}


Of the sample $0.16 \%$ have graduated from a secondary school, $26.23 \%$ have graduated from a high school, $70.76 \%$ have graduated from a university, $2.83 \%$ have an MBA degree and over. Of the sample, $15.67 \%$ have less than 1 year work experience, $42.93 \%$ have $1-5$ years work experience, $27.74 \%$ have 6-10 years work experience and $13.63 \%$ have 11 years and over work experience. Of the respondents $50.80 \%$ have 1-3 years experience of the use of information system, $40.20 \%$ have 46 years experience of the use of information system, and $9 \%$ have 7 years and over experience of the use of information system.

Table 2. Results of factor analysis

\begin{tabular}{lrr}
\hline \multicolumn{2}{c}{ KMO and Bartlett's Test } \\
\hline Kaiser-Meyer-Olkin Measure of Sampling Adequacy. & 0.92 \\
Bartlett's Test of Sphericity & Approx. Chi-Square & 36371.35 \\
& df & 190 \\
& Sig. & 0.001 \\
\hline
\end{tabular}

The scale was subjected to principal components analysis with varimax rotation. The KMO values was 0.92 and Barlett's Test of Sphericity reached statistical significance $(\mathrm{p}<.001)$, supporting the factorability of the correlation matrix. Principal component analysis revealed the presence of four components, explaining 32.88 per cent, 11.29 per cent, 7.07 per cent and 6.41 per cent of the variance respectively. The responses of law clerks were analyzed by factor analysis and four main dimensions were obtained. These are namely; performance and effort expectancy, attitude toward using technology, anxiety, and security and risk. These four factors that eigenvalues higher than 1 are explaining 57.49 per cent of total variance. Cronbach's alpha coefficient was 0.72 for 20 items in our questionnaire. Statements about variables were prepared in 5 point Likert type scale $(1=$ strongly disagree, $\ldots, 5=$ strongly agree). The statements used in the questionnaire were adapted from various studies. ${ }^{5}$ These statements are presented in Table 3.

5 Thomson, R. L., Higgins, C. A., Howell, J. M.: Personal Computing: Toward a Conceptual Model of Utilization. MIS Quarterly. 15 125-- 143 (1991); Davis, F. D.: Perceived Usefulness, Perceived Ease of Use, and User Acceptance of Information Technology. MIS Quarterly. 13 319-340 (1989); Compeau, D., Higgins C. A., Huff, S.: Social Cognitive Theory and Individual Reactions to Computing Technology: A Longitudinal Study. MIS Quarterly. 23 145-158 (1999); Moore, G. C., Benbasat, I.: Development of an Instrument to Measure the Perceptions of Adopting an Information Technology Innovation. Information Systems Research. 2 192--222 (1991); Venkatesh, V.: Determinants of Perceived Ease of Use: Integrating Control, Intrinsic Motivation, and Emotion into the Technology Acceptance Model. Information Systems Research. 11 342--365 (2000); Belanger, F., Carter, L.: Trust and Risk in E-government Adoption. Journal of Information Systems. 17165 --176 (2008); Taylor, S., Todd, P.: Assessing IT Usage: The Role of Prior Experience. MIS Ouarterly. 19 561-570 (1995). 
Table 3. Factor loadings, variance percents of factor analysis with varimax rotation

\begin{tabular}{lr}
\hline \multicolumn{2}{c}{ Factor 1: Performance and effort expectancy } \\
\hline Eigenvalue: $6.58 \quad$ \% of variance: $32.88 \quad$ cumulative \%: 32.88 & FA \\
\hline I would find the system useful in my job on my side. & 0.82 \\
Susceptibility to the computer in using information systems make it easier to \\
do my job. \\
I would find practical to use information systems. & 0.76 \\
I would find beneficial to use information systems in my job on behalf of & 0.73 \\
judiciary systems. & 0.65 \\
I would find beneficial to use information systems in my job on behalf of & 0.62 \\
judiciary systems to provide the transparency. & \\
\hline \multicolumn{2}{c}{ Factor 2: Attitude toward using technology } \\
\hline Eigenvalue: $2.26 \quad$ cumulative $\%: 44.18$ \\
\hline I am glad of the number of steps in the transaction. & FA \\
Information systems help me to make more effective decisions. & 0.71 \\
I am glad to be satisfied my information processing requirements. & 0.69 \\
I am pleased from the information systems in general. & 0.66 \\
The system makes my work more interesting. & 0.58 \\
\hline
\end{tabular}

\section{Factor 3: Anxiety}

\begin{tabular}{lr}
\hline Eigenvalue: $1.41 \quad$ \% of variance: $7.07 \quad$ cumulative \%: 51.25 & FA \\
\hline I hesitate to use the system for fear of making mistakes I cannot correct. & 0.83 \\
It scares me to think that I could lose a lot of information using the system by & 0.76 \\
making wrong transaction. & 0.72 \\
I am worried about using the system. & 0.65 \\
The system is somewhat intimidating to me. & 0.64 \\
\hline It is impossible to correct the mistakes or too difficult.
\end{tabular}

Factor 4: Security and risk

\begin{tabular}{lr}
\hline Eigenvalue: $1.25 \quad$ \% of variance: $6.24 \quad$ cumulative \%: 57.49 & FA \\
\hline Knowledge in information system cannot be changed by unauthorized people. & 0.73 \\
Unauthorized entry to information system is not possible. & 0.72 \\
There is no danger of leaking information from information system. & 0.70 \\
Information system is reliable. & 0.63 \\
Violations of security in information systems are determined by judicial com- & 0.47 \\
petent authorities. & \\
\hline
\end{tabular}

\section{Conclusion}

In this study, the profile of law clerks using judiciary informatics in Turkey was examined. And also their uses of judiciary informatics in terms of the dimensions of performance and effort expectancy, attitude toward using technology, security and risk and anxiety were analyzed. The demographic findings indicate that it is a job that men prefer more, and $96 \%$ of them under the age of 44 . Most of them have graduated 
from a university. Of the sample 70\% have 1-10 years work experience and half of them have 1-3 years of experience of the use of information systems. The responses of law clerks were analyzed by factor analysis and as a result four main dimensions were namely; performance and effort expectancy, attitude toward using technology, security and risk and anxiety. These four factors that eigenvalues higher than 1 are explaining 57.495 per cent of total variance.

It can be said that law clerks are one of the most active users of judiciary informatics in Turkey. In order to increase performance and productivity in judicial services it seems necessary to know the profile of the internal users especially law clerks in judiciary informatics. In this meaning, the contribution of the findings of this study to HCI can be taken into account.

\section{References}

1. Baier, P.R.: The Law Clerks: Profile of an Institution. Vanderbilt Law Review 26, 11251177 (1973)

2. Belanger, F., Carter, L.: Trust and Risk in E-government Adoption. Journal of Information Systems 17, 165-176 (2008)

3. Compeau, D., Higgins, C.A., Huff, S.: Social Cognitive Theory and Individual Reactions to Computing Technology: A Longitudinal Study. MIS Quarterly 23, 145-158 (1999)

4. Crump, D.: Law Clerks: Their Roles and Relationships with Their Judges. Judicature 69, 236-240 (1986)

5. Davis, F.D.: Perceived Usefulness, Perceived Ease of Use, and User Acceptance of Information Technology. MIS Quarterly 13, 319-340 (1989)

6. Engler, R.: And Justice for All-including the Unpresented Poor: Revisiting the Roles of the Judges, Mediators, and Clerks. Fordham Law Review 67, 1987-2070 (1998-1999)

7. Mahoney, J.D.: Law Clerks: For Better or for Worse? Brooklyn Law Review 54, 321-345 (1988)

8. Moore, G.C., Benbasat, I.: Development of an Instrument to Measure the Perceptions of Adopting an Information Technology Innovation. Information Systems Research 2, 192 $222(1991)$

9. Newland, C.A.: Personal Assistants to Supreme Court Justices: The Law Clerks. Oregon Law Review 40, 299-317 (1961)

10. Taylor, S., Todd, P.: Assessing IT Usage: The Role of Prior Experience. MIS Ouarterly 19, 561-570 (1995)

11. Thomson, R.L., Higgins, C.A., Howell, J.M.: Personal Computing: Toward a Conceptual Model of Utilization. MIS Quarterly 15, 125-143 (1991)

12. Venkatesh, V.: Determinants of Perceived Ease of Use: Integrating Control, Intrinsic Motivation, and Emotion into the Technology Acceptance Model. Information Systems Research 11, 342-365 (2000)

13. Venkatesh, V., Morris, M.G., Davis, G.B., Davis, F.D.: User Acceptance of Information Technology: Toward a Unified View Author(s). MIS Ouarterly 27, 425-478 (2003) 